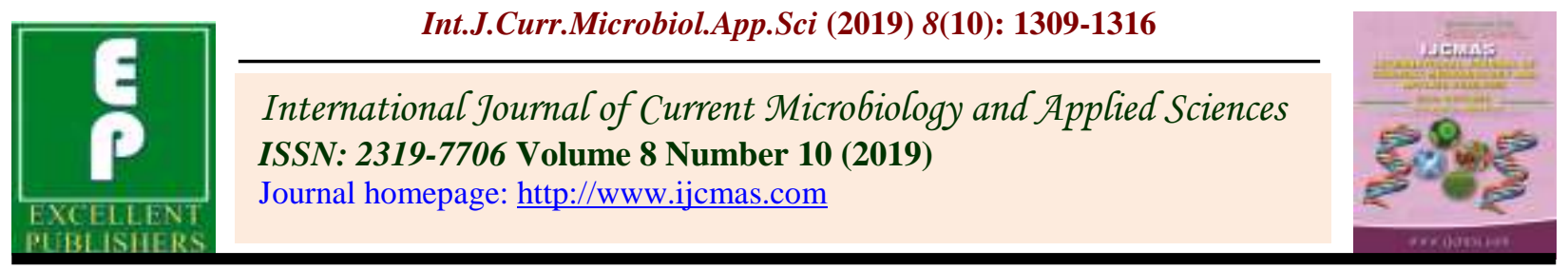

Original Research Article

https://doi.org/10.20546/ijcmas.2019.810.153

\title{
Effect of Drumstick (Moringa olifera) Leaf Meal as a Natural Feed Additive on Serum Lipid Profile of Broilers
}

\author{
P. B. Meshram, R. A. Patil, P. V. Padghan, A. K. Parade, \\ B. S. Gaikwad and S. S. Shinde* \\ Department of Animal Husbandry and Dairy Science, College of Agriculture, Latur, India \\ *Corresponding author
}

\begin{tabular}{|c|}
\hline $\begin{array}{l}\text { Ke y w o r d s } \\
\text { Body weight gain, } \\
\text { Serum lipid profile }\end{array}$ \\
\hline Article Info \\
\hline $\begin{array}{l}\text { Accepted: } \\
\text { 12 September } 2019 \\
\text { Available Online: } \\
10 \text { October } 2019\end{array}$ \\
\hline
\end{tabular}

A B S T R A C T

An experiment was conducted the effects of drumstick leaf meal as a natural feed additive on serum lipid profile of broilers was investigated for a period of sixth weeks. Moringa oleifera leaf meal was substituted for standard broiler ration as a $\mathrm{T}_{1}$ (control), $\mathrm{T}_{2}, \mathrm{~T}_{3}$ and $\mathrm{T}_{4}$ in the four different diets. Eighty, day-old broiler chicks (Vencob-430) are randomly divided into four equal groups containing 5 replicates of 20 chicks were offered a standard broiler diet $\left(\mathrm{T}_{1}\right)$ and drumstick leaf meal addition in the diet of broilers @ 0.5\% $\left(\mathrm{T}_{2}\right), 1.0 \%\left(\mathrm{~T}_{3}\right)$ and $1.5 \%\left(\mathrm{~T}_{4}\right)$ on dry matter basis by partial of control diet for 42 days. Moringa olifera leaf meal at the $0.5 \%$ level significantly $(\mathrm{P}<0.05)$ improved the body weight, feed consumption, serum profile and economics of broilers production. There was significant $(\mathrm{P}<0.05)$ serum total glucose, triglyceride, albumin in MOLM supplemented birds. However, non-significant $(\mathrm{P}>0.05)$ variation was observed in cholesterol, HDLcholesterol, LDL-cholesterol LDL/HDL ratio and total protein and globulin in diet. The results from the present study, it could be suggested that the use of drumstick leaf meal as a feed additive at the level of 0.5 per cent as it improved the significantly better serum lipid profile of broiler production.

\section{Introduction}

Feeds and feeding are an integral part of broiler production that claims between 60$70 \%$ of total cost of production and at the same time, it dictates the production strength and quality. Poultry feed costs in developing countries are a continuing challenge. Improved feed efficiency and reduced feed costs make poultry production a remunerative one. Moringa olifera is one of the plants that can be utilized in the preparation of poultry feeds. The plant apart from being a good source of vitamins and amino acids, it has medicinal uses. Moringa olifera, otherwise it has been used in the treatment of numerous diseases (Gbasi et al., 2000) including heart disease and obesity due to its hypocholesterolemic property (Olugbemi et al., 2010) also reported this quality. Moringa 
olifera leaves have the calcium equivalent of 4 glasses of milk, 3 times the iron of spinach, 4 times the amount of vit $\mathrm{A}$ in carrot, and 2 times protein in milk. The leaves of Moringa are good source of protein, vitamins A, B and $\mathrm{C}$ and minerals such as calcium and iron.

The leaves of Moringa have high protein content which is between $20-33 \%$ on a dry weight basis.

The protein is of high quality having significant qualities of all the essential amino acid. Moringa olifera leaves contain a high level of vitamins A, B, C and calcium (Murro et al., 2002).

The herbal growth promoters for poultry can create optimum condition for normal vigorous growth by acting various ways. The dietary use of herbal growth promoter increases the performance of broiler by increasing live weight gain and FCR. Epidemiological studies have specified that Moringa olifera leaves are a good source of nutrition and display antitumor, anti-inflammatory, anti-ulcer, antifungal, anti-choresterol. It improves FCR and enhances immune response of birds. The herbal growth promoters for poultry can create optimum condition for normal vigorous growth by acting various ways. The successful use of herbal growth promoter will fetch more profit to poultry farmer by efficient conversion of feed consumed to body constituents. Moringa is a potential plant that could be used to enhance immune response and to improve intestinal health of broiler chicken.

\section{Materials and Methods}

Eighty, day old, commercial straight run broiler chicks (Vencobb-430) strain was obtained from Huma-hatcheries, Latur (Maharashtra). All the experimental chicks were individually weighed and banded and then randomly distributed in to four treatments of 20 chicks with four replication of 5 chicks in each treatment on similar body weight basis. All the experimental chicks were reared for 42 days on deep litter system in a wellventilated shed. Proper brooding of chicks was done by providing sufficient heat and light by using electric bulbs in each treatment for first three weeks of age. The standard temperature of brooding was $32-35^{\circ} \mathrm{C}$ for first week. A weekly reduction of $3^{0} \mathrm{C}$ was done till brooder temperature reaches to $27^{\circ} \mathrm{C}$ by third week of age. Afterword sufficient artificial light was provided during night hours throughout the experimental period. Fresh, clean and cool drinking water was provided to bird's adlabitum. All the precautionary measures against diseases were taken throughout the experimental period of six weeks. The dietary treatments $T_{1}-100$ parts of standard broiler ration without supplement (control sample), $\mathrm{T}_{2^{-}}-99.5$ parts of standard broiler ration +0.5 Parts of drumstick leaf meal, $\mathrm{T}_{3^{-}} 99.00$ parts of standard broiler ration +1.00 Parts of drumstick leaf meal and $\mathrm{T}_{4}-98.5$ part standard broiler ration +1.5 Parts of drumstick leaf meal. All the broiler chicks were fed with ground maize first two days of age. Chicks feed standard feed purchased from market for three periods of 2-10 days birds fed with prestarter, 11-21 days birds fed with broiler starter and 22-42 days birds fed with broiler finisher. The diets were fed ad-libitum to experimental groups by adding required amount of Moringa olifera leaf meal as per treatment. The per cent ingredient composition of experimental broiler ration that is for prestarter, starter and finisher in Table 1 respectively.

\section{Collection of blood}

At the end of experiment three ml blood was collected from wing vein in syringe without any anticoagulant and kept in clot activator tubes. The serum constituent's parameter was determined by local pathological laboratories 
and diagnostic institute and estimated the following blood serum parameters. Serum constituent's estimation of Glucose, Serum Cholesterol, Serum Triglycerides, Serum HDL i.e. (High density lipoprotein), Serum LDL i.e. (Low density lipoprotein), LDL/HDL Ratio, Blood Protein, Albumin, Globulin.

\section{Chemical Analysis}

The chemical analysis of the experimental broiler ration was carried out as per A.O.A.C. (1995) for all the proximate principles.

\section{Statistical Analysis}

The treatment wise data on cumulative body weight gain in body weight, feed consumption and feed conversion ratio and blood serum constituents were subjected to analysis of variance of Complete Randomized Design CRD (Snedecor and Cochran, 1982).

\section{Results and Discussion}

\section{Cumulative body weight}

The average weekly growth performance of experimental birds at body weight of broilers from day old to sixth weeks of age in all dietary treatments were subjected to CRD and the results are presented in Table 2.

The initial body weights of broilers were almost same in all dietary treatments indicating the treatment groups were homogenous in nature. The statistical analysis on the weekly body weight of broiler birds under four different treatments during each week revealed significant $(\mathrm{P}<0.05)$ difference during all the weeks except initial, first and second week. After the sixth week it was observed from Table 2 that the average cumulative body weights of broiler birds in the treatment group $\mathrm{T}_{2}$ were significantly $(\mathrm{P}<0.05)$ higher as compared to control in $\mathrm{T}_{1}$ and $\mathrm{T}_{4}$ group where as at par with $\mathrm{T}_{3}$. The average body weight of obtained in $T_{2}$ group was significantly superior over $T_{3}$ and those in $\mathrm{T}_{4}$ group. Body weight gain by birds in $\mathrm{T}_{2}$ group differed significantly from $\mathrm{T}_{3}$. The body weight of treatment $T_{1}$ Control was significantly lower as compared to all the treatments i.e. $\mathrm{T}_{2}, \mathrm{~T}_{3}$ and $\mathrm{T}_{4}$. The growth pattern indicated that optimum beneficial effect of Moringa olifera leaf meal supplementation as an herbal feed additive could be achieved at 0.5 per cent level of inclusion. In the present study, the effect of supplementation of MOLM was evaluated, it was found that addition of $0.5 \%$ moringa leaf meal in broiler ration exhibited better weight gain than without moringa leaf meal. It may be due to the presence of the fatty acids, or due to stimulating effect on the digestive system of broilers.

The results obtained in this present study corresponds with the results of Sarker et al., (2017) who showed that the supplementation of broiler chicks receiving 1.5 per cent moringa leaf meal was significantly $(\mathrm{P}<0.05)$ higher final body weight as compared to control group. Similar trend was also observed by Akinola, (2018) who indicated that the same result as the weekly live body weight of MOLM fed 0.5 and $1.5 \%$ these two treatments are at par with each other broilers diet remained significantly $(\mathrm{P}<0.05)$ higher than control group. The present results are also line with the findings obtained by Banjo, (2012) who revealed that chicks fed on $2 \%$ MOLM recorded significantly $(\mathrm{P}<0.05)$ higher body weight as compared to all tested groups. Khan, (2016) also noticed that addition of 1.2 $\%$ MOLM in broiler ration exhibited better weight than without MOLM. Ochi, (2015) indicated that addition of MOLM during the growing period had higher body weight for chicks fed diets containing $2.0 \%$ MOLM as compared to control diet. The present findings are also in accordance with Nkukwana et al., 
(2012) who found that birds supplemented with Moringa olifera leaf meal had higher body weight than the birds fed the control diets. Dey and Partha, (2013) also observed that Moringa olifera leaves supplemented diet was improved the body weight of broilers.

Table.1 Chemical composition of experimental broiler ration

\begin{tabular}{|c|c|c|c|c|}
\hline \multirow{2}{*}{$\begin{array}{c}\text { Sr. } \\
\text { No. }\end{array}$} & Nutrients & \multicolumn{3}{|c|}{ Per cent in ration } \\
\cline { 3 - 5 } & & $\begin{array}{c}\text { Pre- } \\
\text { starter }\end{array}$ & Starter & Finisher \\
\hline $\mathbf{1}$ & Crude protein & 23.35 & 21.64 & 20.20 \\
\hline $\mathbf{2}$ & Crude fibre & 3.92 & 3.96 & 3.99 \\
\hline $\mathbf{3}$ & Ether extract & 4.95 & 5.08 & 5.12 \\
\hline $\mathbf{4}$ & Total ash & 6.2 & 6.1 & 5.93 \\
\hline $\mathbf{5}$ & Acid insoluble ash & 1.57 & 1.60 & 1.62 \\
\hline $\mathbf{6}$ & Nitrogen free extract & 61.58 & 63.22 & 64.76 \\
\hline $\mathbf{7}$ & Metabolizable energy & 2982.5 & 3065.7 & 3198.8 \\
\hline $\mathbf{8}$ & (kcal/kg) & & & $158.35: 1$ \\
\hline
\end{tabular}

Table.2 Average weekly cumulative body weight (g) per bird

\begin{tabular}{lcccccc}
\hline Items & \multicolumn{7}{c}{ MOLM levels } \\
\cline { 2 - 7 } & $\mathbf{T}_{\mathbf{1}}$ & $\mathbf{T}_{\mathbf{2}}$ & $\mathbf{T}_{\mathbf{3}}$ & \multicolumn{1}{c}{$\mathbf{T}_{\mathbf{4}}$} & & \\
\hline Initial & 46.97 & 47.33 & 47.40 & 47.23 & 0.15 & $\mathrm{NS}$ \\
\hline $1^{\text {st }}$ week & 166.00 & 159.00 & 159.50 & 158.00 & 8.96 & $\mathrm{NS}$ \\
\hline $2^{\text {nd }}$ week & 362.00 & 356.25 & 355.00 & 354.50 & 19.91 & $\mathrm{NS}$ \\
\hline $3^{\text {rd }}$ week & $682.25^{\mathrm{a}}$ & $834.67^{\mathrm{d}}$ & $810.25^{\text {cd }}$ & $796.20^{\text {bc }}$ & 22.26 & $*$ \\
\hline $4^{\text {th }}$ week & $1214.50^{\mathrm{a}}$ & $1323.00^{\mathrm{d}}$ & $1291.50^{\text {bc }}$ & $1305.99^{\text {cd }}$ & 15.94 & $*$ \\
\hline $5^{\text {th }}$ week & $1824.28^{\mathrm{a}}$ & $1982.69^{\mathrm{d}}$ & $1911.50^{\text {cd }}$ & $1897.24^{\text {bc }}$ & 23.37 & $*$ \\
\hline $6^{\text {th }}$ week & $2473.25^{\mathrm{a}}$ & $2626.99^{\mathrm{b}}$ & $2580.62^{\mathrm{b}}$ & $2562.99^{\mathrm{ab}}$ & 33.08 & $*$ \\
\hline
\end{tabular}

(Significant $(\mathrm{P}<0.05)$ means under each class in the same column with different superscripts differ significantly) 
Table.3 Serum lipid profile of broiler chickens fed drumstick leaf meal diet

\begin{tabular}{lcccccc}
\hline Parameter & \multicolumn{7}{c}{ MOLM levels } \\
\cline { 2 - 7 } & T1 & T2 & T3 & T4 & SE & CD at 5\% \\
\hline Glucose $(\mathrm{mg} / \mathrm{dl})$ & $102.00^{\mathrm{a}}$ & $123.75^{\mathrm{b}}$ & $116.75^{\mathrm{b}}$ & $109.00^{\mathrm{a}}$ & 2.37 & $*$ \\
\hline Cholesterol (mg/dl) & 135.25 & 123.00 & 128.50 & 132.25 & 4.07 & NS \\
\hline TG $(\mathrm{mg} / \mathrm{dl})$ & $129.75^{\mathrm{b}}$ & $113.50^{\mathrm{a}}$ & $125.50^{\mathrm{b}}$ & $126.50^{\mathrm{b}}$ & 3.29 & $*$ \\
\hline HDL $(\mathrm{mg} / \mathrm{dl})$ & 80.50 & 89.00 & 82.25 & 8650 & 5.07 & $\mathrm{NS}$ \\
\hline LDL $(\mathrm{mg} / \mathrm{dl})$ & 35.25 & 32.00 & 33.25 & 32.50 & 4.19 & $\mathrm{NS}$ \\
\hline LDL/HDL Ratio & 35.25 & 32.00 & 33.25 & 32.50 & 4.19 & $\mathrm{NS}$ \\
\hline A) Blood Protein $(\mathrm{g} / \mathrm{dl})$ & 2.20 & 2.41 & 2.33 & 2.36 & 0.13 & $\mathrm{NS}$ \\
\hline a. Albumin $(\mathrm{g} / \mathrm{dl})$ & $1.42^{\mathrm{a}}$ & $1.49^{\mathrm{b}}$ & $1.44^{\mathrm{a}}$ & $1.48^{\mathrm{b}}$ & 0.15 & $*$ \\
\hline b. Globulin $(\mathrm{g} / \mathrm{dl})$ & 1.02 & 0.94 & 0.98 & 0.96 & 0.04 & $\mathrm{NS}$ \\
\hline
\end{tabular}

(Similar superscript do not differ significantly $(\mathrm{P}<0.05)$ from each other within a row)

HDL - (High density lipoprotein), LDL- (Low density lipoprotein), TG-Triglyceride

The results obtained in this experiment are in concurrence with findings of Okafor et al., (2014) they reported that the growth rate of broilers in the tested group was higher compared with control. Whereas past researchers also observed non-significant differences when supplemented with MOLM. Aderinola et al., (2013) concluded that the inclusion level of leaf meals in broiler diets results depressed growth performance.

On the other hand, present results are disagree with that reported by Gadzirayi et al., (2012) they noticed the negative effect of high level of MOLM on body weight of broilers. In same contest the Gakuya et al., (2014) conducted the effect of MOLM in the broiler diet and concluded its negative effect on weight.

Moringa olifera leaves contain major nutritional minerals needed for healthy growth of animals including the poultry. The utilization of Moringa olifera improving the nutritional value of broilers and also yield optimum performance of broiler birds.

\section{Serum lipid profile}

The average mean of serum constituents like glucose, cholesterol, triglyceride, high density lipoprotein (HDL), low density lipoprotein (LDL) HDL and LDL ratio, blood protein, albumin and globulin of broilers as influenced of dietary inclusion of drumstick leaf meal it was estimated at the end of experiment and the results are presented in Table 3. The results shows serum lipid profile of the broiler chickens fed varying levels of drumstick leaf meal. It was observed that the serum lipid profile parameters differs significantly $(\mathrm{P}<0.05)$ except cholesterol, HDL, LDL, HDL and LDL ratio, blood protein and globulin which had no significant difference $(\mathrm{P}>0.05)$ among the dietary treatment. Also results indicated that the concentration of glucose increased as the level of drumstick leaf meal increased in the diet, the difference level of glucose in $\mathrm{T}_{2}$ was significantly $(\mathrm{P}<0.05)$ more as compared to $T_{1}$ and $T_{3}, T_{4}$. The differences level of cholesterol in $T_{1}, T_{2}, T_{3}$ and $T_{4}$ were non-significant. Which indicated that the 
concentration of cholesterol decreased in $0.5 \%$ inclusion of drumstick leaf meal.

Which indicated that the concentration of cholesterol decreased in inclusion of MOLM diet the results of cholesterol fraction shows a decrease in serum cholesterol confirming the hypocholesterolemic properties of Moringa olifera leaf meal.

Triglyceride was lowest in $\mathrm{T}_{1}$ and highest in $\mathrm{T}_{1}$ i.e. control group without supplemented moringa leaf meal which had significantly $(\mathrm{P}<0.01)$ higher level of serum triglyceride than $T_{2}$ group where as at par with $\mathrm{T}_{3}$ and $\mathrm{T}_{4}$.

The HDL was highest in $\mathrm{T}_{2}$ in of $0.5 \%$ level of moringa leaf meal and lowest value in $\mathrm{T}_{1}$ in control group. The values of HDL clearly showed that all supplemented moringa leaf meal treatment was quantitatively higher values than control. The differences in level of LDL cholesterol in $T_{1}, T_{2}, T_{3}$ and $T_{4}$ were nonsignificant.

The $T_{2}$ had lowest LDL level followed by $\mathrm{T}_{3}$, $\mathrm{T}_{4}$ and highest level of LDL was found in $\mathrm{T}_{1}$ i.e. control. The LDL / HDL ratio was highest in $\mathrm{T}_{2}$ in $0.5 \%$ level of moringa leaf meal and lowest in $\mathrm{T}_{1}$ control group. This proved the positive effect of moringa leaf meal in serum lipid profile. The differences in level of total protein in $T_{1}, T_{2}, T_{3}$ and $T_{4}$ were nonsignificant.

The $T_{2}$ had highest level followed by $T_{4}, T_{3}$ and lowest level of total protein was found in $\mathrm{T}_{1}$. The albumin was highest in $\mathrm{T}_{2}$ in $0.5 \%$ level of moringa leaf meal and lowest value in $\mathrm{T}_{1}$ in control group.

The values of albumin clearly showed that all supplemented moringa leaf meal treatment is significantly higher values than control except $\mathrm{T}_{3}$. The globulin was highest in $\mathrm{T}_{1}$ in $0.0 \%$ level of control and lowest value in $T_{2}$ in control group. The values of globulin clearly showed that all supplemented moringa leaf meal treatment is significantly lower values than control. Similar findings was observed by Balami et al., (2018) who reported that the HDL-cholesterol, cholesterol level and triglyceride was significantly decreased at 42 days of age. Similar observations were also found by Sarker et al., (2017) reported that the decreasing the plasma level in broiler chicken by addition of MOLM in the diet, which indirectly revealed about the hypocholesterolemic effect of Moringa olifera. The results of present study could be correlated with the result of Akinola, (2018) who reported that the Moringa olifera leaf meal results better cholesterol. The result revealed that better (HDL-cholesterol) of the 0.5\%-1.0\% levels of MOLM, triglycerides, and low density lipoprotein (LDL-cholesterol) with no effect on high density lipoprotein cholesterol. This selective reduction in (LDLcholesterol) results in the improvement of the ratio of HDL- cholesterol to LDL-cholesterol. Similar findings with Bolu et al., (2013) who reported that the LDL-cholesterol decreased as the 5\% level of MOLM increased. The other some similar results reported by Mardevi et al., (2017) and concluded that the addition of MOLM at level $10 \%$ in the ration is the optimum level to decrease the triglyceride of meat without disturbing the HDL content in meat addition of MOLM upto $12 \%$ in the ration does not give a negative effect on weight gain.

Other contrary findings with this study showed that, MOLM supplementation in the diet of broiler chickens had no significant influence on the lipid profile of broiler chickens, reported by Zanu et al., (2012) and Gakuya et al., (2014). The present results are also disagree with Aderinola et al., (2013) who reported that the serum parameters were less affected except triglyceride and the cholesterol that was significantly decreased as the inclusion level increased. 
The blood lipid profile has an important role in the performance of broilers. In this regard, it can be indicated that the plasma very low density lipoprotein is a useful parameter to infer the degree of fatness in chickens. The natural herbs and natural products, which are highly effective in lowering serum cholesterol in broilers, boost immunity and prevent diseases thereby producing lean and healthy broiler chickens. The high content of fat in the tissues is affected by the levels of triglycerides in the serum derived from fatty synthesis in the liver. As with triglycerides, cholesterol in the body is mainly obtained from the synthesis in the liver.

The amount synthesized depends on the body's needs and amounts obtained from food: such as carbohydrates, proteins or fats. Preventing the build-up of chemicals in broiler meat can be done by mixing with natural ingredients, without reducing the quality of the ration added natural ingredients are Moringa olifera leaf meal.

This study indicated that supplementation of drumstick leaf meal powder at the different levels of $0.5 \%, 1.0 \%$ and $1.5 \%$ in the broiler chick's diet.

The inclusion of Moringa olifera leaf meal in broiler ration substantially decreased serum cholesterol, triglyceride and increased the glucose, total protein level and improved the LDL/HDL ratio. Hence, it is beneficial to use Moringa olifera leaf meal as a growth promoter or feed supplement in commercial broiler production.

\section{References}

Aderinola O. A., Rafiu T. A., Akinwumi A. O., Alabi T. A. and Adeagbo O. A. (2013). Utilization of Moringa Oleifera Leaf as Feed Supplement in Broiler Diet. International Journal of Food, Agriculture and Veterinary Sciences, 3(3): 94-102.
Akinola L. A. and Ovotu N. (2018). Influence of Moringa oleifera Leaf Meal on Egg Lipids and Blood Constituents of Laying Hens. International Journal of Experimental Agriculture, 22(2):1-9.

A. O. A. C. (1995). Official Methods of Analysis, $16^{\text {th }}$ ed. Association of Official Analytical Chemist, Washington D. C.

Balami A. G., Ndahi J. J., Gadzama J. J., Enam S. J., Chiroma M. A., Abdu P. A., Wakawa A. M., Aluwong T. and Oladele S. B. (2018). Effect of Moringa oleifera Feed Supplementation on the Serum Biochemical Profile of Broilers Challenged with Very Virulent Infectious Bursal Disease Virus. Journal of Advanced Veterinary and Animal Research, 5(2):155-165.

Banjo O. S. (2012). Growth and Performance as Affected by Inclusion of Moringa oleifera Leaf Meal in Broiler Chicks Diet. Journal of Biology, Agriculture and Healthcare, 2(9):35-45.

Bolu S. A., Suleiman F. F. and Adeyemi K. D. (2013). Effects of moringa oleifera Leaf Meal on the Performance, Hematology and Serum Biochemistry of Broiler Chickens. Niugini Department of Agriculture the Papua New Guinea University of Technology, 5(2):1-9.

Dey A. and Partha S. D. (2013). Influence of Moringa oleifera Leaves as a Functional Feed Additive on the Growth Performance, Carcass Characteristics and Serum Lipid Profile of Broiler Chicken. Indian J. Anim. Res., 47(5):449-452.

Gakuya D. W., Mbugua P. N., Kavoi B. and Kiama S. G. (2014). Effect of Supplementation of Moringa oleifera Leaf Meal in Broiler Chicken Feed. International Journal of Poultry Science, 13(4):208-213.

Gadzirayi C. T., Masamha B., Mupangwa J. F. and Washaya S. (2012). Performance of Broiler Chickens Fed on Mature Moringa oleifera Leaf Meal as a Protein Supplement to Soybean Meal. International Journal of Poultry Science, 11(1):5-10.

Gbasi S., Nwobodo E. and Ofili J. O. (2000). Hypo-cholesterolenic Affects of Crude Extract of Leaf of Moringa Oleifera Lam in High Fat Diet Fed Wistar Rats. Journal of Ethonophimacology, 69(1):21-25. 
Khan I., Zaneb H., Masood S., Yousaf M. S., Rehman H. F. and Rehman H. (2016). Effect of Moringa oleifera Leaf Powder Supplementation on Growth Performance and Intestinal Morphology in Broiler Chickens. Journal of Animal Physiology and Animal Nutrition, 14(4):1-8.

Nkukwana T. T. (2012). Effect of Moringa Oleifera Leaf Meal on Growth Performance, Gut Integrity, Bone Strength, Quality and Oxidative Stability of Meat from Broiler Chickens. South African Journal of Animal Science, 44(3):2-3.

Mardewi N. K., Etty Suwitari N. K., Sri Rukmini N. K., (2017). Effect of Moringa (Moringa oleifera) Leaf Meal Supplementation in Broiler Chicken Ration on Weight of Internal Organs, HDL and Triglyceride Levels. Journal of Biological Sciences, 1(2):46-51.

Mariam E. A., Afaf A., Faten K., Gehan R., Mohammed N. and Boareki. (2017). Effect of Varying Levels of Moringa as Replacement for Soyabean Meal in Broiler Ration. Kuwait J. Sci., 44(3):96-103.

Murro J. K., Mulikanmbele V. R. M. and Sarwatt S. V. (2002). Moringa oleifera Leaf Meal Can Replace Cotton Seed Cake in the Concentrate Mix Feed with Rhodes Grass (Chloris Gayana) Hay for Growing Sheep. Livestock Research for Rural Development, 15(11):123-132.

Ochi E. B., Elbushra M. E., Fatur M., Abubakr O. I. and Hafiz A. (2015). Effect of Moringa (Moringa oleifera L.) Seeds on the Performance and Carcass Characteristics of
Broiler Chickens. Journal of Natural Sciences Research, 5(8):66-73.

Okafor I. N., Ezebuo F. C. and Azodo N. T. (2014). Effect of Moringa oleifera Leaf Protein Concentrate Supplemented Feed on Growth and Nutritional Parameters in Broilers. World Applied Sciences Journal, 32(1):133-138.

Olugbemi T. S., Mutayoba S. K. and Lekule F. P. (2010). Effect of Moringa (Moringa oleifera) Inclusion in Cassava Based Diets Fed to Broiler Chickens. I. J. Poultry. Sci., 9(4):363367.

Onunkwo D. N. and George O. S. (2015). Effects of Moringa oleifera Leaf Meal on the Growth Performance and Carcass Characteristics of Broiler Birds. J. Agri. Vet. Sci., 8(3):63-66.

Sarker S. K., Masud R., Khatun H., Faruque S., Sarker N. R., Sharmin F. and Islam N. (2017). Moringa Leaf Meal as Natural Feed Additives on the Growth Performance and Meat Quality of Commercial Broiler Chicken. Asian J. Med. Biol. Res., 3(2):240244.

Snedecor G. W. and Cochran W. G. (1982). Statistical Methods. 6th Edition, Oxford and IBH Publishing co. Culcutta, Bombay and Delhi. 168-181.

Zanu H. K., Asiedu P., Tampuori M., Abada M. and Asante M. (2012). Possibilities of Using Moringa (Moringa oleifera) Leaf Meal as a Partial Substitute for Fishmeal in Broiler Chickens Diets. $J$ of Animal and Feed Research, 2 (1):70-75.

\section{How to cite this article:}

Meshram, P. B., R. A. Patil, P. V. Padghan, A. K. Parade, B. S. Gaikwad and Shinde, S. S. 2019. Effect of Drumstick (Moringa olifera) Leaf Meal as a Natural Feed Additive on Serum Lipid Profile of Broilers. Int.J.Curr.Microbiol.App.Sci. 8(10): 1309-1316. doi: https://doi.org/10.20546/ijcmas.2019.810.153 